University of Tulsa College of Law

TU Law Digital Commons

Articles, Chapters in Books and Other Contributions to Scholarly Works

1994

\title{
Mistake of Fact in the Objective Theory of Justification: Do Two Rights Make Two Wrongs Make Two Rights...?
}

Russell Christopher

russell-christopher@utulsa.edu

Follow this and additional works at: http://digitalcommons.law.utulsa.edu/fac_pub

Part of the Criminal Law Commons

Reprinted by special permission of Northwestern University School of Law, The Journal of Criminal Law and Criminology.

Recommended Citation

85 J. Crim. L. \& Criminology 295 (1994).

This Article is brought to you for free and open access by TU Law Digital Commons. It has been accepted for inclusion in Articles, Chapters in Books and Other Contributions to Scholarly Works by an authorized administrator of TU Law Digital Commons. For more information, please contact daniel-bell@utulsa.edu. 


\section{CRIMINAL LAW}

\section{MISTAKE OF FACT IN THE OBJEGTIVE THEORY OF JUSTIFICATION: DO TWO RIGHTS MAKE TWO WRONGS MAKE TWO RIGHTS . . . ?}

\section{RUSSELL L. CHRISTOPHER*}

"The most difficult problems in criminal theory are generated by dissonance between reality and belief, between the objective facts and the actor's subjective impression of the facts." 1 One particularly thorny instantiation of this difficulty is whether the use of defensive force by actors who reasonably, but mistakenly, believe that they are being attacked should be justified or only excused. ${ }^{2}$ There are two

* Research Associate, Columbia University School of Law. A.B. 1983, Hamilton College; J.D. 1988, University of Michigan Law School. I wish to thank Thelma Christopher and Maria Pagano for their criticisms of earlier drafts.

1 George P. Fletcher, Rethinking Criminal Law 683 (1978). See also Douglas N. Husak, Philosophy of Criminal Law 211-12 (1987) ("The problem that has bedeviled criminal theory since its inception is to provide a principled account of when mistakes have a bearing on liability."); 1 WAyne R. LAfave \& Austin W. Scott, JR., Substantive Criminal LAw 575 (1986) ("No area of the substantive criminal law has traditionally been surrounded by more confusion than that of ignorance or mistake of fact or law.").

2 See e.g., B. Sharon Byrd, Wrongdoing and Attribution: Implications Beyond the JustificationExcuse Distinction, 33 WAYNE L. REv. 1289, 1321 (1987) (footnote omitted) ("The vast majority of criticism of the justification-excuse distinction involves the issue of mistake."); Joshua Dressler, Justifications and Excuses: A Brief Review of the Concepts and the Literature, 33 WAYNE L. REV. 1155, 1161-63 n.22 (1987) (identifying the issue as one of the three principal controversies regarding justifications which have been argued in the literature); Benjamin B. Sendor, Mistakes of Fact: A Study in the Structure of Criminal Conduct, 25 WAKE FOREST L. REv. 707, 753 (1990) ("The question of whether a mistake about justificatory circumstances should be classified as a justification defense or as an excuse defense has generated a lively scholarly debate in recent years."); $i d$. at 708 ("a thorny issue of criminal law theory: whether mistakes about justificatory circumstances should be classified as justifications or excuses"); Gunter Stratenwerth, The Problem of Mistake in Self-Defense, in 2 Justification and Excuse: Comparative Perspectives 1055, 1057 (Albin Eser \& George Fletcher eds., 1987) ("The question of how to handle the problem of putative [mistaken] self-defense has been one of the most controversial topics in German case law and doctrine for many years.").

One commentator has even expressed skepticism about whether the problem of mis- 
main approaches to this problem of mistaken justification. The first approach is the common law or Anglo-American approach, ${ }^{3}$ which views the justificatory circumstances from the subjective perceptions of the actor: force is eligible for justification if an actor believes it is necessary or justified (subjective theory of justification). ${ }^{4}$ The second approach is the civil law or Continental approach which regards the justificatory circumstances from an objective viewpoint external from the actor: force is eligible for justification if it actually is necessary (objective theory of justification). ${ }^{5}$ There are two principal versions of the Continental approach. Professor Paul Robinson champions a purely objective theory of justification, in which an actor's subjective

taken justification is susceptible to resolution: "Perhaps no single argument can resolve this dispute, and for good reason." Douglas N. Husak, Justifications and the Criminal Liability of Accessories, 80 J. CRim. L. \& CRIMINology 491, 507 (1989).

Justifications and excuses are defenses for conduct that satisfies the definition of a criminal offense. The philosopher J.L. Austin, in his paper "A Plea For Excuses," distinguished justifications from excuses as follows: "In the one defence, briefly we accept responsibility but deny that it was bad [justification]; in the other we admit that it was bad but don't accept full, or even any, responsibility [excuse]." John L. Austin, Philosophical PAPERS 176 (J.O. Urmson \& Geoffrey J. Warmock eds., 2d ed. 1970). Fletcher supplies the following concise account of the distinction: "A justification speaks to the rightness of an act; an excuse, to whether the actor is accountable for a concededly wrongful act." FLETCHER, supra note 1 , at 759 . Justifications and excuses also affect the rights of other parties in the following general ways:

Justified action is warranted action; similar actions could properly be performed by others; such actions should not be interfered with by those capable of stopping them; and such actions may be assisted by those in a position to render aid. If action is excused, the actor is relieved of blame but others may not properly perform similar actions; interference with such actions is appropriate; and assistance of such actions is wrongful.

Kent Greenawalt, The Perplexing Borders of Justification and Excuse, 84 Colum. L. Rev. 1897, 1900 (1984) (footnote omitted) (citing FLETCHER, supra note 1, at 760-61; Albin Eser, Justification and Excuse, 24 Aм. J. CoMP. L. 621, 622-23 (1976)).

Regarding the importance of the distinction, one commentator has stated that "[p]erhaps the most significant and controversial research program among contemporary criminal theorists is the investigation of the advantages and limitations of applications of the distinction between justification and excuse." Husak, supra, at 491 (footnote omitted). For a recent overview of the justification-excuse distinction and the debate surrounding it, see Dressler, supra, at 1155.

3 George P. Fletcher, The Right and the Reasonable, 98 HARv. L. REv. 949, 971-80 (1985).

4 A typical requirement of a subjective theory of justification is that an actor's belief be reasonable. See, e.g., I Model Penal Code and Commentaries $\$ 3.09$, Comment 2, at 151 (Official Draft and Revised Comments 1985) ("unreasonableness of an alleged belief quite properly is considered as evidence that it was not in fact held"); MODEL PENAL CODE $\$ 3.04$, Explanatory Note, at 32 (Official Draft 1985) (if an actor's "belief is mistaken and is recklessly or negligently formed, he may then be prosecuted for an offense of recklessness or negligence under Section 3.09").

5 Fletcher, supra note 3, at 971-80. An objective theory of justification is employed throughout continental Western Europe including French and German criminal law codes. It is also followed in Eastern Europe, the former Soviet Union, Latin America, and Japan. Id. 
perceptions and mental state are irrelevant. ${ }^{6}$ Professor George Fletcher suggests a hybrid theory requiring both the actual necessity of an actor's force and an actor's subjective belief in the necessity. of that force. ${ }^{7}$ The subjective theory would justify an actor's mistaken use of force; either version of the objective theory would only excuse it.

Fletcher, lauded for resurrecting the justification-excuse distinction in modern criminal law, 8 contends that "we can use the concepts

62 Paul H. Robinson, Griminal Law Defenses $\$ 122$ (f), at 27 (1984) ("To summarize, an objective theory of justification suggests that no subjective mental elements should play a part in the formulation of justification defenses."); $i d$. $\$ 121$ (c), at 7 ("[J]ustification principles ... are stated in a purely objective form, without any mention of the actor's subjective mental state.").

Robinson's views on justification and criminal defenses have enjoyed considerable acclaim: Kenneth Campbell, Offence and Defence, in CRIMinal LAW AND JusTice 73, 76 (I.H. Dennis ed., 1987) (footnote omitted) ("Any discussion of defenses for quite some time to come is going to be indebted to the work of Professor Paul Robinson."); Husak, supra note 2 , at $491 \mathrm{n} .2$ ("The most outspoken champions of this distinction [justification-excuse] in Anglo-American law are George Fletcher and Paul Robinson."); id. at 498 ("Since Robinson has provided the most detailed and sophisticated account of defenses in Anglo-American criminal theory, it is important to examine his position on justifications.").

For a critique of the purely objective theory of justification justifying an actor unaware of existing justificatory circumstances see Russell L. Christopher, Unknowing Justification and the Logical Necessity of the Dadson Principle, I5 Oxford J. LEGAL STUD. (forthcoming 1995).

7 Fletcher, supra note 3, at 972 (emphasis added) ("Justification-harmony with the Right is an objective phenomenon. Mere belief cannot generate a justification, however reasonable the belief might be."); see FLETGHER, supra note 1, at 576 ("Claims of justification always require a union of objective elements and a subjective intent."); George $P$. Fletcher, The Right to Life, 13 GA. L. Rev. 1371, 1384-85 (1979) ("objective circumstances are not enough to support a claim of justification; the actor must act with the right reasons"); George P. Fletcher, Mistake in the Model Penal Code: A False False Problem, 19 Rutcers L.J. 649, 663 (1988) ("The complex of criteria bearing on the justification of self-defense consist of objective and subjective elements: the objective factors of aggression and necessary response, and a subjective requirement of intent or knowledge.").

8 See, e.g., the following commentators who credit Fletcher for reviving interest in the concepts of justification and excuse:

In recent years the academic landscape has changed. George Fletcher is credited with "crying in the wilderness" about the lack of academic attention to the concepts of justification and excuse. Through his writings, Professor Fletcher has sought to clarify the meaning of the two terms and to demonstrate the importance of the concepts in a mature legal system.

Professor Fletcher's scholarship has borne fruit. The field is now fairly rich in literature....

Dressler, supra note 2, at 1159 (footnotes omitted) (quoting Greenawalt, supra note 2, at 1897); Joshua Dressler, New Thoughts About the Concept of Justification in the Criminal Law: $A$ Critique of Fletcher's Thinking and Rethinking, 32 U.C.L.A. L. Rev. 61, 63 (1984) ("George Fletcher is largely responsible for this modern interest."); Eser, supra note 2, at 621 ("with the exception of George Fletcher, who seems to stand alone in fully recognizing the fundamental distinction"); Greenawalt, supra note 2, at 1897-98 (footnote omitted) ("Crying in the wilderness, however, are a few possibly prophetic voices, among which the loudest and most eloquent is George Fletcher's."); Robert F. Schopp, Justification Defenses and Just Con- 
of justification and excuse only when we are willing to accept the logical consequences of applying them to particular cases of conflict." However, the logical consequences of applying Fletcher's and Robinson's objective theories of justification are logical contradictions and paradoxes. Examining an altered hypothetical case of conflict propounded by Fletcher himself reveals that the objective theories are self-contradictory. Each actor's conduct in the altered hypothetical is paradoxically justified and not justified at the same time. Unless such logical contradictions are deemed acceptable, ${ }^{10}$ the objective theory's future influence may be in jeopardy.

Fletcher has derided the Anglo-American approach to justification, which utilizes the subjective theory, as "still in Plato's cave and .. . barely perceiv[ing] the shadows of criminal theory."11 But applying the subjective theory of justification to the same hypothetical does not generate any logical contradictions or paradoxes. Thus, the objective theories of justification may be seeing some shadows of their own. Though perhaps flawed, the conceptually consistent subjective theory of justification may now be viewed as preferable to the selfcontradictory objective theories.

The central difference between the two approaches is evident from one of Fletcher's hypotheticals: ${ }^{12}$ Suppose Dan reasonably, but incorrectly, believes that Allan is wrongfully attacking him. In what he reasonably believes to be justified self-defense, Dan attacks Allan. Allan then uses defensive force against Dan. Under a subjective theory of justification, both Dan's reasonably mistaken force and Allan's force would be justified. ${ }^{13}$ Under an objective theory of justification,

victions, 24 PAC. L.J. 1233, 1238 (1993) ("Much of the contemporary discussion of justification defenses takes the form of a debate between George Fletcher and a series of critics. ..."); A.T.H. Smith, Rethinking the Defence of Mistake, 2 OXFORD J. LEGAL STUD. 429, 430 (1982) ("[W]e can be grateful to Fletcher for helping us to see the point more clearly."); Glanville L. Williams, The Theory of Excuses, 1982 CRIM. L. Rev. 732, 732 ("We are indebted to Professor George Fletcher for reviving interest in the distinction between justification and excuse in criminal law.").

9 George P. Fletcher, Should Intolerable Prison Conditions Generate a Justification or an Excuse For Escape?, 26 U.C.L.A. L. REv. 1355, 1358 (1979).

10 A comment by Fletcher suggests that logical contradictions in legal theory should not be considered acceptable: "In some circles of supposedly critical thought, it is even fashionable to tolerate contradictions as an inescapable feature of legal thought. These antitheoretical and antirational strains in legal thought discourage dialogue and preclude advances in our understanding of legal phenomena." George P. Fletcher, Paradoxes in Legal Thought, 85 Colum. L. REv. 1263, 1264 (1985) (footnote omitted). For more of Fletcher's thoughts on logical inconsistencies in legal discourse, see infra text accompanying note 27, note 80, text accompanying note 122, note 132 .

11 George P. Fletcher, Proportionality and the Psychotic Aggressor: A Vignette in Comparative Criminal Theory, 8 IsRAel L. Rev. 367, 390 (1973).

12 Fletcher, supra note 3, at 972-73.

13 Id. at $973,975$. 
however, Dan's force is "putatively"14 justified (i.e., excused), and only Allan's force is actually justified. ${ }^{15}$

Fletcher argues that because the subjective theory "assimilat[es] a putative justification to an actual justification [, it] undermines the matrix of legal relationships affected by a [valid] claim of justification."16 Under the subjective theory, a third-party intervenor's force in defense of either Dan or Allan or even both could be justified. Furthermore, if Allan realized that Dan believed he was justified, the use of force by Allan (the innocent victim) against Dan (the initial aggressor) would not be justified. ${ }^{17}$ By justifying only Allan's force, the objective theory avoids incompatible or conflicting justifications (between Dan and Allan), the legal anarchy of an intervenor justifiably using force against an innocent victim (Allan) or whichever actor the intervenor chooses, and the anomaly of barring an innocent victim from using justified force.

Advocates of the subjective theory counter that incompatible justifications are not a serious flaw ${ }^{18}$ and that, in any event, incompatible justifications also occur under the objective theory. ${ }^{19}$ Yet Fletcher's "incompatibility thesis" 20 dictates that incompatible justifications aris-

14 Fletcher has defined "putatively" justified actors as those who believe that their force is justified because of a reasonable mistake of fact such that if they had perfect or complete knowledge of the situation, they would not reasonably believe force was justified. Although a subjective theory of justification would justify such an actor's force, an objective theory would only excuse such actors. FLETCHER, supra note 1, at 762-69; Fletcher, supra note 3, at 972.

15 Fletcher, supra note 3 , at $972-73$.

16 FLETCHER, supra note 1 , at 763.

17 Fletcher, supra note 3, at 975 n.116.

18 See, e.g., Charles Fried, Rught and Wrong 48 (1978) (conflicting or incompatible justifications are "unfortunate but in no sense a contradiction" and are "a possibility in any theory which judges the morality of an action from the perspective of an actor's factual perceptions."); Greenawalt, supra note 2, at 1909 n.33 (incompatible justifications are merely a "supposed paradox"); $i d$. at 1921 (incompatible justifications are only a "claimed anomaly").

19 See, e.g., Dressler, supra note 8, at 63-64, 88-89, 91 n.168; David Dolinko, Note, Intolerable Conditions as a Defense to Prison Escapes, 26 U.C.L.A. L. REv. 1126, 1180 n.298 (1979).

20 "It would strike most Continental theorists as contradictory to say that both sides to [a] conflict were justified in their use of force. It is in the nature of justification, they would say, that if two people are locked in conflict, only one person can be justified." FLETCHER, supra note 1, at 767 (footnote omitted); Fletcher, supra note 3, at 975 ("in any situation of physical conflict, where only one party can prevail, logic prohibits us from recognizing that more than one of the parties could be justified in using force. I shall refer to this proposition as the "incompatibility thesis."');

If a convict has the right to leave a burning jail, a guard cannot also have a right to keep him confined. If Dan has the right to use force against Allan, Allan cannot also have the right to use force against Dan. This strikes me as the natural way to speak about rights. The impossibility of inconsistent rights seems implicit in the grammar of rights discourse. So far as justifications generate rights, therefore, the impossibility of inconsistent justifications follows. 


\section{ing under an objective theory are "logically impossible."21}

Professor Kent Greenawalt has provided, in Fletcher's terms, "the most sustained and sophisticated defense" of justifying the mistaken actor. ${ }^{22}$ First, Greenawalt expresses skepticism that any bright-line distinction between justifications and excuses can be drawn. Second, Greenawalt proposes a number of hypotheticals illustrating that an actor may mistakenly assess the justificatory circumstances, but still act in a morally praiseworthy manner. Since such conduct is not morally wrong, it must be justified. ${ }^{23}$ Robinson claims that Greenawalt's hypotheticals rely on reasonable mistakes of fact, which only generate putative justifications and "suggest a preference for the comparative conceptual clarity of an objective theory." ${ }^{24}$ Professor Michael Moore

Id. at 978 (footnote omitted); Fletcher, supra note 9, at 1360 ("in cases of incompatible conduct, one and only one party must have a right to prevail"); $i d$. at 1358 ("if two people are making an effort to execute incompatible acts, both of them cannot be justified. Only one can have a right to engage in his desired act and therefore be justified in doing so."). In a more recent article, Fletcher has termed the "impermissibility of logically inconsistent claims of justification" as the "one Right thesis": "The thesis holds that only one side to a zero-sum conflict (where one gains as much as the other loses) can act justifiably and thus be in the Right." George P. Fletcher, The Psychotic Aggressor-A Generation Later, 27 IsRaEL L. REv. 227, 236 (1993).

Fletcher's thesis also finds expression in German philosophy and criminal law theory. Professor Albin Eser states:

On the one hand it seems quite obvious that you cannot exercise justifiable self-defense against an act that is itself an act of justified self-defense because otherwise you get into a circle which perhaps none of the participants would leave unwounded, but in which all would be justified in having wounded the respective other victim. If the law is to prevent "civil war" in which each participant claims to have justice on his side, then the right of self-defense, as well as virtually any other justification, cannot be on both sides. In this respect, in German jurisprudence the so-called "self-defense test" has become a "rule of thumb" for determining whether a person should have the right of self-defense against an invasion of his rights: This can only be the case if the invasion is not itself justified.

Albin Eser, Justification and Excuse: A Key Issue in the Concept of Crime, in 1 JustifiCATION AND Excuse: Comparative Perspectives 17, 31-32 (Albin Eser \& George Fletcher eds., 1987) (footnote omitted). Regarding whether two actors in physical conflict could both be justified, or in the right, the philosopher Immanuel Kant concluded that "[i]t is evident that were there such a right the doctrine of Right would have to be in contradiction with itself." Immanuel Kant, The Doctrine of Right 235, in THE METAPHYSICS OF MORALS 60 (Mary Gregor trans., 1991) (cited by Fletcher, supra, at 236).

21 Fletcher, supra note 3, at 978.

22 Fletcher, supra note 20, at 241.

23 Greenawalt, supra note 2, at 1908-09. See also Peter W. Low et Al., Criminal Law 541-48 (1982); Dolinko, supra note 19, at 1179 n.297; Dressler, supra note 8; Kent Greenawalt, Distinguishing Justifications from Excuses, 49 LAw \& CoNTEMP. Probs. 89 (Summer 1986); Husak, supra note 2, at 507-08; Thomas Morawetz, Reconstructing the Criminal Defenses: The Significance of Justification, 77 J. CRIM. L. \& CrImINolocy 277, 289 n.42 (1986) (supporting some form of a subjective theory of justification).

24 Paul H. Robinson, Rules of Conduct and Principles of Adjudication, 57 U. CHI. L. Rev. $729,752 \mathrm{n.57}(1990)$. Robinson's complete response is as follows:

From the perspective of objective justification, it is entirely predictable that Greenawalt would conclude that the borders of justification and excuse are "perplexing," as 
argues that Greenawalt's hypotheticals are all based on the premise that justification is subjective; the examples beg the question of whether justification should be objective. ${ }^{25}$

By altering Fletcher's above hypothetical, this Article will demonstrate that both Fletcher's and'Robinson's objective theories of justification succumb to a logical contradiction that leaves the subjective theory unscathed. Suppose that instead of only Dan holding the reasonably mistaken belief, Dan and Allan each reasonably, but incorrectly, believe that the other is attacking him. As a result of their reasonably mistaken beliefs, Dan and Allan each attack the other in what each reasonably believes is justified self-defense.

How would an objective theory treat this altered version of Fletcher's hypothetical? In the original hypothetical, Fletcher concluded that Dan's force was not actually justified but only putatively justified. Similarly, if only Allan, not Dan, held the reasonably mis-

the title of his article suggests. [Greenawalt, supra note 2]. By defining justifications to include reasonably mistaken justifications, his attempt to distinguish justification and excuse is an attempt to distinguish mistaken justifications from excuses, which cannot successfully be done, I believe, because mistaken justifications are excuses. I believe that his conclusion, that the doctrine ought not systematically embody the justification-excuse distinction, must be qualified. The justification-excuse distinction is troublesome only if one adopts a subjective theory of justification, as Greenawalt does. Most, if not all, of his troublesome cases are clear and unproblematic under an objective theory of justification. In fact, one might conclude that the point he has demonstrated in his article is not perplexing borders of justification and excuse, but rather that the perplexing borders created by the use of a subjective theory suggest a preference for the comparative conceptual clarity of an objective theory. Id.

For other defenses of the objective theory against the criticisms of commentators who support a subjective theory, see Byrd, supra note 2, at 1333-41; Fletcher, supra note 20, at 23646; Fletcher, supra note 3, at 977-78; Fletcher, supra note 9; Winfried Hassemer, Justifcation and Excuse in Criminal Law: Theses and Comments, B.Y.U. L. REv. 573, $607-08$ (1986); Terry L. Price, Faultless Mistake of Fact: Justification or Excuse?, 12 CRIM. JUST. ETHICs 14 (Summer/Fall 1993); 2 RoBinson, supra note 6, §121(c), at 7-9; Schopp, supra note 8, at 1280-82; Sendor, supra note 2, at 753-74.

25 Michael S. Moore, Causation and the Excuses, 73 CAL. L. REv. 1091, 1096 n.19 (1985) ("I choose to treat them [reasonably mistaken justifications] as excused actions, because this is the only way I can make the [justification-excuse] distinction survive the elegant counterexamples to be found throughout Greenawalt's paper."); MicHAEL S. MOORE, ACT and Crime: The Philosophy of action and tis Implications for Criminal Law 183 (1993):

Greenawalt's mistake is with his initial premise. ... So long as one classifies mistaken beliefs about elements of normally justificatory defence to be excuses, there is no 'perplexing border' here. ...

Although Greenawalt elegantly details a variety of other examples in his nicely written article, all are premised on the assumption that justification is a subjective matter, that is, that it is governed by what the accused reasonably believes and not by the objective facts of the matter. Change that assumption, as I have urged we must, and none of such examples present any conceptual problems for the line between the actus reus (including absence of justification) and the excuse requirements.

Id. 
taken belief and attacked Dan, Allan's conduct would not be actually justified but only putatively justified. Therefore, it is tempting to conclude that in the altered hypothetical both Dan and Allan are mistakenly or putatively justified. However, that contention is shown to be clearly wrong. This Article will demonstrate that, under the objective theories, Dan's force and Allan's force are each, paradoxically, justified and not justified at the same time. As a result, the objective theories of justification are self-contradictory.

At stake is not merely which theory of justification is logically consistent, but also the very nature of justification in criminal law. By tinkering with the requisite elements which an actor's force must satisfy in order to be justified under an objective theory, the paradox can be avoided. Yet, a subsequent hypothetical will be advanced which demonstrates that the logical contradiction cannot be circumvented satisfactorily without excising the very heart of the objective theories: Fletcher's incompatibility thesis and Robinson's correlate principle that force cannot justifiably be used against justified force. ${ }^{26}$ Their removal will leave a radically reconfigured justification formulation and will eliminate the primary support for the theory's tenets regarding the nature of justification and criminal responsibility. Consequently, proponents of, and jurisdictions employing, an objective theory will be faced with the conundrum of maintaining their selfcontradictory theory, amending it to an eviscerated form, or abandoning it in favor of a subjective theory.

Fletcher suggests that when "[c]onfronted by data not explainable by the prevailing theory, theorists must either confess the incompleteness or inadequacy of their system or revise their tools of analysis to accommodate the anomaly." 27 If so, advocates of, and jurisdictions employing, an objective theory of justification in the criminal law will now have such a choice before them.

261 Robinson, supra note $6, \S 36$ (a) (2), at 165 (footnote omitted) (citing FletCHER, supra note 1, at 760-61, 869-70) ("Where an aggressor has a justification defense, the proper rule is clear: justified aggression should never be lawfully subject to resistance or interference."); 2 RoBINSON, supra note $6, \S 131$ (b) (2), at 74 ("In order to trigger a defensive force defense the aggressor must unjustifiably threaten harm to the defendant."); id. at 75 (actor "may not, however, lawfully defend against justified aggression."); id. § 3-1(3), Model Codifications, app. A, at 564 ("Except as otherwise provided by law, conduct that is justified is privileged and may not be lawfully resisted or interfered with, and may be lawfully assisted by any other person."); Paul H. Robinson, A Theory of Justification: Societal Harm as a Prerequisite for Criminal Liability, 23 U.C.L.A. L. REv. 266, 278 (1975) ("It is suggested here that any justified act-not just those specified by statute-should be free from defensive force."); id. ("[I]f burning the field is justifiable, it would be inconsistent to conclude that a person may lawfully prevent it... [O]nly one of the acts can be justified, and the criminal code should require the nonjustified act to yield to the justified.").

27 Fletcher, supra note 10, at 1263-64. 
Part I of this Article will present a variation of Fletcher's above hypothetical revealing the objective theories to be self-contradictory. Part II introduces another hypothetical through which further logical contradictions are derived under the objective theories. Part III presents, considers, and rejects arguments against the conclusion that the objective theories are self-contradictory. Part IV discusses the procedural ramifications of contradictions in the objective theories. Part $\mathrm{V}$ explores the consequences of the self-contradictions for the objective theories' understanding of the underlying nature of justification and criminal responsibility. Part VI sketches various amendments to the objective theories which might dislodge the paradoxes, and concludes that each amendment creates further conceptual anomalies for the objective theories. Part VII summarizes the main currents of this Article and lays down a challenge to jurisdictions employing, and advocates of, an objective theory to either satisfactorily expunge the contradictions or abandon the objective approach in favor of the subjective theory of justification.

\section{Logical Contradictions Derived From Fletcher's and Robinson's ObJective TheORIES OF Justification}

Applying either Fletcher's or Robinson's objective theory to the following variation on Fletcher's hypothetical ${ }^{28}$ (Hypothetical 1) will result in a logical contradiction.

Suppose Dan and Allan each reasonably, but incorrectly, believe that the other is attacking him. In fact, neither Dan nor Allan is using force against anyone. Dan and Allan each decide to use what each believes is justified self-defense force against the other. Dan and Allan each use similar force against the other simultaneously. Each actor's use of force interferes with the other actor's use of force.

\section{A. FLETCHER'S AND ROBINSON'S OBJECTIVE THEORIES}

Actors are putatively justified, under an objective theory, if they believe that their force is necessary or justified, but had they possessed complete knowledge of the circumstances they would not or could not have reasonably believed that their use of force was necessary or justified. ${ }^{29}$ It is possible to argue that both Dan and Allan are putatively justified since each incorrectly believed that the other was attacking him prior to either one using force. In Fletcher's original hypotheti-

28 Fletcher, supra note 3 , at $972-73$.

29 FLETCHER, supra note 1, at 762-69. See Greenawalt, supra note 2, at 1907 ("People often engage in conduct that would be justified if the actual facts were precisely as they believed them to be, but would not be justified if the actual facts had been fully comprehended."). 
cal, in which only Dan is mistaken, no one would dispute that Dan is putatively justified, but not actually justified, under an objective theory. Since Dan's beliefs and conduct in this altered hypothetical are identical to his beliefs and conduct in Fletcher's original hypothetical, it might seem that Dan is putatively justified (but not actually justified), under an objective theory in the altered hypothetical as well. Similarly, if it was Allan who mistakenly attacked Dan, Allan would be putatively justified under an objective theory. Since Allan's beliefs and conduct are identical in the above situation, as in the altered hypothetical, it would appear that Allan is also putatively justified. It is tempting, therefore, to conclude that both Dan and Allan, in the altered hypothetical, are putatively justified under an objective theory. But that conclusion is incorrect.

To ascertain whether the actors are putatively justified, it is necessary to examine whether each actor would believe that his force was necessary or justified if he had complete knowledge of the situation. Suppose Dan had complete knowledge of the circumstances. $\mathrm{He}$ would have known that Allan was not actually attacking him (prior to their simultaneous force), that Allan believed that Dan was attacking him (prior to their simultaneous force), and that Allan would imminently use force against him. If Dan had not used force against Allan, Allan would have used force against Dan unimpeded by Dan's force. As a result, Dan would have sustained an even more forceful blow from Allan. Therefore, even if Dan had complete knowledge of the situation, Dan would have reasonably and correctly believed his force to be necessary and justified. Consequently, Dan is not putatively justified. The same form of argument demonstrating that Dan is not putatively justified also demonstrates that Allan is not putatively justified.

Considering Dan's and Allan's cases separately leads to the conclusion that neither Dan nor Allan is putatively justified. Yet, Dan not being putatively justified is based on Allan not having complete knowledge of the situation; and Allan not being putatively justified is based on Dan not having complete knowledge of the situation. Neither Dan nor Allan is putatively justified since if each had complete knowledge of the situation, each would know that the other did not have complete knowledge of the circumstances and that the other would imminently use force based on an incorrect belief.

One might argue that since each actor's being not putatively justified depends on the other actor not having complete knowledge, only one of the actors is not putatively justified. However, the standard for determining whether an actor is not putatively justified does not re- 
quire that other actors have complete knowledge. ${ }^{30}$ It requires only that the actor in question have complete knowledge. For example, in determining whether Dan was not putatively justified, the only issue is whether Dan, himself, could still reasonably believe that his force was necessary or justified if he had complete knowledge of the circumstances-Allan's or anyone else's beliefs are irrelevant to this inquiry. Since both Dan and Allan-individually-meet this standard, neither is putatively justified.

Although neither actor is putatively justified, it is nonetheless possible that neither actor's use of force is justified in self-defense under Fletcher's and Robinson's objective theories of justification. While Robinson's theory does not require that an actor have any particular mental state, Fletcher's theory requires that an actor act with justificatory intent or . knowledge of the justificatory circumstances. ${ }^{31}$ Although Dan perhaps lacks knowledge of the justificatory circumstances, he does act with justificatory intent since he believes that his use of force is justified. ${ }^{32}$

Further, suppose that the force Dan used was proportional and "the minimal force necessary." ${ }^{33}$ Objectively viewed, was Dan's force

30 In order for an actor to be not putatively justified, his belief that his force is necessary or justified would not be altered if he had complete knowledge of the situation. See supra note 29 and accompanying text.

31 FLETCHER, supra note 1, at 559-60, 565.

32 Fletcher states that " $\mathrm{t}]$ here might be a stronger and weaker version of the rule; the stronger version would require the actor to be motivated exclusively by the justificatory criteria; the weaker version, that he merely be aware of them." Id. at 559 (footnote omitted). Curiously, Dan satisfies the stronger version of the rule, but does not satisfy the weaker version.

33 Fletcher, supra note 3, at 973 ("Allan may use the minimal force necessary to ward off Dan's attack."); FLETCHER, supra note 1, at 870 ("There are two requirements for the exercise of necessary force: (1) that the means chosen be the minimal force necessary under the circumstances; and (2) that the force not be unreasonable or disproportionate relative to the interest defended."). Yet it is not entirely clear that Fletcher's theory fully endorses the principle of proportionality. Compare id. (force must be proportional) with FLETCHER, supra note 1, at 871-74 and Fletcher, supra note 11, at 371-80 (a requirement that force be proportional may conflict with the absolute right to defend one's autonomy). One commentator views Fletcher as supporting proportionality as a moral criterion, but not as a legal requirement. Nancy M. Omichinski, Note, Applying the Theories of Justifiable Homicide to Conflicts in the Doctrine of Self-Defense, 33 WAYNE L. REv. 1447, 1455 (1987). Since the necessity and proportionality of Dan's force in the original hypothetical was not an issue, Dan's and Allan's similar force in the altered hypothetical would presumably also not be problematic. In any event, each actor's force in the altered hypothetical does not exceed the degree of force necessary for effective self-protection since each actor's force only partially impeded the other actor's force. Additionally, since each actor used the same moderately harmful force against the other, the possible requirement of proportionality would be satisfied.

Robinson's model self-defense provision is as follows:

Conduct constituting an offense is justified if:

(1) an aggressor unjustifiably threatens harm to the actor; and 
necessary? If Dan had not used force against Allan, Allan would have unjustifiably attacked Dan, unimpeded by any force from Dan. As a result, Dan would have sustained an even more forceful blow from Allan. Therefore, it may reasonably be maintained that Dan's force was necessary and justified.

A similar argument also demonstrates that Allan's force is necessary and justified. Since Allan's beliefs about Dan and actions against Dan are identical to Dan's beliefs about Allan and Dan's actions against Allan, the same reasoning showing Dan's force to be justified would also reveal Allan's force to be justified. Under the objective theories, however, force used against justified force cannot be justified. Fletcher's incompatibility thesis and Robinson's correlate principle dictate that in any conflict between two opposed parties, only one of the parties can be justified. ${ }^{34}$ If both Dan's force and Allan's force are justified, then each used force against the other's justified force and thus paradoxically neither actor's use of force would be justified. ${ }^{35}$

Yet if neither actor's use of force is justified, then each actor used force against unjustified force. Force used against unjustified force is eligible to be justified. Since Dan's force and Allan's force satisfy all of the requirements under the objective theories, their use of force is justified. Therefore, if neither actor's force is justified, then paradoxi-

(2) the actor engages in conduct harmful to the aggressor:

(a) when and to the extent necessary for self-protection,

(b) that is reasonable in relation to the harm threatened.

2 RoBINson, supra note $6, \S 3-3$, Model Codifications, app. A, at 565 .

An actor "is privileged to use only that degree of force actually necessary for self-protection. ... [ [T] he force used is not justified if the individual actor could protect himself effectively with less." Id. $\S 121(\mathrm{a})$, at 5. An actor's force must also be reasonable or proportional:

The proportionality requirement places a limit on the maximum harm that may be used in protection or furtherance of an interest. It bars justification when the harm caused by the actor may be necessary to protect or further the interest at stake, but is too severe in relation to the value of that interest.

Id. Each actor's force in the hypothetical does not exceed the degree of force necessary for self-protection since each actor's force only partially impeded the other actor's force. Additionally, since each actor used similarly harmful force against the other, the proportionality requirement is satisfied.

34 See supra notes 20, 26.

35 The paradox may be set out as follows:

(1) Dan's force and Allan's force are each justified.

(2) Each actor was justifiably attacked.

(3) Each actor used force against justified force.

(4) According to Fletcher's incompatibility thesis and Robinson's correlate principle, force used against justified force cannot be justified.

(5) Therefore, neither Dan's force nor Allan's force is justified.

The conclusion in step (5) contradicts the premise in step (1) from which the conclusion is derived. 
cally both actors' use of force is justified. ${ }^{36}$

If both actors' use of force is justified or neither actor's use of force is justified, then a paradox ensues. If both actors' use of force is justified, then neither actor's use of force is justified; if neither actor's use of force is justified, then both actors' use of force is justified. ${ }^{37}$ As a result, if both actors' use of force is justified or neither actor's force is justified, each actor's force is both justified and not justified under the objective theories of justification.

Although the contention that both actors' use of force is justified or neither actor's force is justified leads to the above paradoxes, the claim that one actor's use of force is justified and the other actor's force is unjustified is also problematic. Since each actor holds the same beliefs about the other actor and each uses similar force at the same time, there is no basis for differentiating between Dan's and Allan's conduct as to which is justified. Furthermore, the "universal" nature of justification-espoused by Robinson and Fletcher-dictates that if one actor's force is justified, a similarly situated actor would also be justified in the use of similar force. ${ }^{38}$ As a result, if either

36 The paradox may be set out as follows:

(1) Neither Dan's force nor Allan's force is justified.

(2) Each actor was unjustifiably attacked.

(3) Each actor used force against unjustified force.

(4) Force used against unjustified force is eligible to be justified.

(5) Each actor's force satisfies all the other requirements in order to be justified

under the objective theories of justification.

(6) Therefore, Dan's force and Allan's force are both justified.

The conclusion in step (6) contradicts the premise in step (1) upon which the conclusion is based.

37 The paradoxical situation is as follows:

(1) If each actor's force is justified, then neither actor's force is justified.

(2) If neither actor's force is justified, then each actor's force is justified.

(3) Same as (1).

(4) Same as (2).

Consequently, a vicious circle is generated.

38 "Claims of justification lend themselves to universalization. That the doing is objectively right (or at least not wrongful) means that anyone is licensed to do it. . . Excuses, in contrast, are always personal to the actor...." FuETCHER, supra note 1, at 761-62. Fletcher also explains the universal character of justification as follows:

When the principles of justification are rendered concrete in particular cases, the result is a precedent that other people may properly rely upon in similar cases. . . In similar cases arising in the future, similarly situated actors may rely on these recognized privileges in planning their conduct. The only requirement for claiming the precedent is the general legal rule that the new case may not be significantly different in its relevant facts.

Id. at 810-11.

Robinson also endorses the universal nature of justification: "Since justification is dependent not on the actor but only on the act, an act which is justifiable when performed by one actor is necessarily justifiable when performed by any actor." Robinson, supra note 26, at 278 n.49. Robinson further states that since the nature of justification is universal, "any other actor engaging in the same conduct under the same objective circumstances must be 
Dan's force or Allan's force is justified, the other's force must also be justified; if either Dan's force or Allan's force is unjustified, the other's force must also be unjustified.

However, according to Fletcher's incompatibility thesis, and Robinson's correlate principle, in order for one actor's force to be justified, the other actor's force must not be justified. Thus, Fletcher's thesis and Robinson's principle are in contradiction with the universal nature of justification depicted by both objective theories. Consequently, it appears that each actor must simultaneously have both the samejustification status as the other actor and a different justification status than the other actor. The resulting paradox may be set forth as follows:

(1) Since there is no relevant basis for differentiating Dan's conduct from Allan's conduct as to which is justified, and the nature of justification is universal, then both actors' use of force is justified or neither actor's use of force is justified.

(2) According to Fletcher's incompatibility thesis and Robinson's correlate principle, if one of the actor's force is justified, then the other actor's force cannot be justified.

(3) Therefore, neither actor's use of force is justified.

(4) Yet if neither actor's use of force is justified, then both actors' use of force is justified.

(5) Same as (2).

(6) Same as (3).

(7) Same as (4).

Consequently, under the objective theories of justification, Dan's use of force and Allan's use of force are each justified and not justified in violation of the law of noncontradiction. ${ }^{39}$ Therefore, whether Dan's use of force or Allan's use of force is justified is paradoxically indeterminate under the objective theories.

\section{B. SUBJECTIVE THEORY (MODEL PENAL CODE)}

Since Dan and Allan each reasonably believed that his own use of force was justified, Dan's force and Allan's force would both be justi-

similarly justified." 2 RoBinson, supra note $6, \S 121$ (c), at 8 .

39 See generally Stephan Korner, Laws of Thought, in 4 Encyclopedia of Philosophy 414 (Paul Edwards et al. eds., Reprint ed. 1972) (discussing the law of noncontradiction or principle of contradiction as one of the three fundamental laws of logical reasoning). One commentator has stated the consequences of violating the law of noncontradiction: "Confusion is the predictable consequence of simultaneous endorsement of irreconcilable positions. It is the penalty attached to violation of one law that even the Supreme Court cannot ignore: the law of noncontradiction." Lawrence A. Alexander, Constitutional Torts, the Supreme Court, and the Law of Noncontradiction: An Essay on Zinermon v. Burch, 87 Nw. U. L. REv. 576, 596 (1993). For Fletcher's view of contradictions in legal thought see supra text accompanying note 9 , note 10 , text accompanying note 27 and infra note 80 , text accompanying note 122 , note 132 . 
fied under $\S 3.04$ of the Model Penal Code (MPC). ${ }^{40}$ That Dan and Allan would have conflicting justifications would not be disturbing or surprising to proponents of the subjective theory since they correctly acknowledge that conflicting justifications will occasionally arise under the subjective theory of justification. ${ }^{41}$

\section{c. CONCLUSION}

Whereas the subjective $\S 3.04$ of the MPC ${ }^{42}$ incurs no conceptual anomalies, both objective theories of justification succumb to conceptual difficulties in handling Hypothetical 1. The contradiction generated under these theories could be avoided in a number of ways. As seen in the presentation of the paradox, the culprits would seem to be Fletcher's incompatibility thesis and Robinson's correlate principle which state that force used against justified force cannot be justified. If Fletcher's thesis and Robinson's principle were removed from the objective theories, both Dan's force and Allan's force would be justified. The conclusion that each actor's force is justified would no longer yield the opposite conclusion that neither actor's force is justified and the self-contradictions would not arise.

Perhaps, however, a less drastic means could be found to avoid the paradoxes. For instance, both objective theories might require (instead of justificatory purpose or knowledge of the justificatory circumstances, as Fletcher's theory requires) ${ }^{43}$ that an actor have knowledge of the justificatory circumstances or such knowledge and justificatory purpose. If neither Dan nor Allan had such knowledge, neither actor's force would be justified under such an amended objective theory. As a result, the conceptual difficulties incurred by the objective theories would be effectively circumvented.

II. Logical Contradiction Derived From Fletcher's and Robinson's Objective Theories Cannot be Avoided by Requiring KNOWLEDge of THE Justificatory Circumstances

Applying the objective theories to the following hypothetical will result in a logical contradiction that cannot be avoided by an amendment requiring knowledge of the justificatory circumstances. Con-

40 Model Penal. Code \$ 3.04(1):

Subject to the provisions of this Section and of Section 3.09, the use of force upon or toward another person is justifiable when the actor believes that such force is immedi-

- ately necessary for the purpose of protecting himself against the use of unlawful force by such other person on the present occasion.

41 See supra note 18.

42 Model Penal Code $\$ 3.04$.

43 FLETCHER, supra note 1 , at 559-60, 565 . 


\section{sider Hypothetical 2:}

Cindy and Joanne, two bitter enemies who have had physical altercations with each other on many occasions, unexpectedly meet each other on a dark, deserted street. Neither wishes to attack the other, yet neither wishes to be unjustifiably attacked. Each reasonably believes that the other will imminently use unjustified force against her. Because of their history of hostile encounters, Cindy reasonably believes that Joanne will unjustifiably use self-defense force because Cindy believes that Joanne believes that Cindy will reasonably, but mistakenly, use self-defense force against her (Joanne). Also due to their history of violence, Joanne reasonably believes that Cindy will unjustifiably use self-defense force because Joanne believes that Cindy believes that Joanne will reasonably, but mistakenly, use self-defense force against her (Cindy). Acting with justificatory intent, each uses similar force against the other simultaneously. Each actor's use of force interferes with the other actor's use of force.

\section{A. FLETCHER'S AND ROBINSON'S OBJECTIVE THEORIES}

Under an objective theory, are Cindy and Joanne putatively justified? If Cindy had complete knowledge of the circumstances, she would have known that Joanne would imminently use force against her, because Joanne believed that Cindy would mistakenly use selfdefense force against her (Joanne). In fact, that is what Cindy actually believes. Thus, Cindy correctly comprehended the circumstances. Furthermore, if Cindy had not used force against Joanne, Joanne would have unjustifiably used force against Cindy, unimpeded by Cindy's force. As a result, Cindy would have sustained an even more forceful blow from Joanne. Therefore, even if Cindy did have complete knowledge of the situation, Cindy would still have reasonably and correctly believed that her force was necessary and justified. Consequently, Cindy is not putatively justified. A similar form of argument would also demonstrate that Joanne is not putatively justified.

Since each actor reasonably believed that her force was justified, each one has the requisite justificatory purpose. Therefore, each one satisfied Fletcher's requirement of having justificatory intent or knowledge of the justificatory circumstances. ${ }^{44}$ Suppose further that the force each actor used was proportional and necessary. ${ }^{45}$ The only remaining issue then is whether the actor in question was unjustifiably threatened or attacked. Since Fletcher's incompatibility thesis and Robinson's correlate principle dictate that force cannot justifiably be used against justified force, if the actor in question was justifiably attacked the actor cannot be justified. Only an unjustified attack or 
threat against an actor would render the actor's force eligible to be justified.

The first consideration is whether Cindy was unjustifiably attacked. This depends on whether Joanne's force is justified. But whether Joanne's force is justified depends on whether Cindy's force is justified. In turn, whether Cindy's force is justified depends on whether Joanne's force is justified. A vicious circle ensues.

If both actors' use of force is justified, then Fletcher's thesis and Robinson's principle would dictate that neither actor's force is justified. Yet if neither actor's use of force is justified, then each actor was unjustifiably attacked. Since Cindy's force and Joanne's force satisfy all of the other requirements for justification under the objective theories, both Cindy's force and Joanne's force would be justified. Yet if both actors' use of force is justified, then according to Fletcher's thesis and Robinson's principle neither actor's use of force is justified.

This circularity can be avoided if one actor's force is justified and the other actor's force is unjustified. There is no relevant basis, however, to differentiate Cindy's conduct from Joanne's conduct as to which is justified. Moreover, the universal nature of justification dictates that if either of the actors' force is justified, then the other's similar force under similar circumstances would necessarily also be justified. ${ }^{46}$ Therefore, either both Cindy's force and Joanne's force are justified, or neither actor's force is justified-a conclusion which leads to the above logical contradiction. ${ }^{47}$

Perhaps the issue can be approached from a different direction. As stated in the hypothetical, each actor believes that the other actor's use of force is unjustified. If it can be determined which actor's belief is correct, then it can be decided which actor's force, if any, is justified. If Cindy's reasonable belief that Joanne would use unjustified force is correct, then Joanne's force is unjustified, Cindy's force is justified, and Joanne's reasonable belief is incorrect. Similarly, if Joanne's reasonable belief that Cindy would use unjustified force is

46 See supra note 38 and accompanying text.

47 The paradoxical situation may be set out as follows:

(1) Since there is no relevant basis for differentiating Cindy's conduct from Joanne's conduct as to which is justified, and the nature of justification is universal, both actors' use of force is justified or neither actor's use of force is justified.

(2) According to Fletcher's thesis and Robinson's principle, if one of the actor's force is justified then the other actor's force cannot be justified.

(3) Therefore, neither Cindy's nor Joanne's force is justified.

(4) Yet if neither Cindy's force nor Joanne's force is justified, then both Cindy's force and Joanne's force are justified.

(5) Same as (2).

(6) Same as (3).

(7) Same as (4).

As a result, a vicious circle ensues. 
correct, then Cindy's force is unjustified, Joanne's force is justified, and Cindy's reasonable belief is incorrect. Thus, it seems that in order for one of the actors to be correct and her force justified, the other actor must be incorrect and her force unjustified.

However, it is impossible to determine which actor is correct and which actor's force is justified. Each actor's relevant thoughts and actions are similar; each holds the same beliefs regarding the other; and each uses similar force, at the same time, against the other. Based on the universal nature of justification, both actors must be correct or neither actor can be correct. If both actors are correct, then neither actor's use of force is justified. But if both are correct, then paradoxically both are incorrect (in order for either to be correct, the other must be incorrect)..$^{48}$ If both actors are incorrect, then both actors' use of force is justified. Therefore, if both Gindy and Joanne are correct, then paradoxically each actor's force is both justified and not justified at the same time.

If neither is correct, then both actors' use of force is justified. Yet if neither is correct, then paradoxically both are correct (in order for either to be incorrect, the other must be correct). ${ }^{49}$ If both are correct, then neither actor's use of force is justified. Therefore, if both Cindy and Joanne are incorrect, then their use of force is both justified and not justified at the same time.

As a result, regardless of whether Cindy and Joanne are both correct or both incorrect, Cindy's force and Joanne's force are each justified and not justified at the same time. The objective theories are selfcontradictory in their treatment of this hypothetical situation.

48 The paradox may be set out as follows:

(I) Both Cindy's and Joanne's reasonable belief that the other would use force unjus-

tifiably is correct.

(2) Therefore, Cindy used unjustified force and Joanne used unjustified force.

(3) Force used against unjustified force is eligible to be justified.

(4) Since Cindy's force and Joanne's force satisfy all the other requirements in order to be justified, Cindy's force and Joanne's force are justified.

(5) Therefore, both Cindy's and Joanne's reasonable belief that the other would use force unjustifiably is incorrect.

The conclusion in step (5) contradicts the premise in step (1) upon which the conclusion is based.

49 The paradox may be set out as follows:

(1) Both Cindy's and Joanne's reasonable belief that the other would use unjustified force is incorrect.

(2) Therefore, Cindy used justified force and Joanne used justified force.

(3) Each actor used force against justified force.

(4) Force used against justified force cannot be justified under an objective theory.

(5) Therefore, neither Cindy's force nor Joanne's force is justified.

(6) Both Cindy's and Joanne's reasonable belief that the other would use unjustified force is correct.

The conclusion in step (6) contradicts the premise in step (1) from which the conclusion is derived. 


\section{B. SUBJECTIVE THEORY (MODEL PENAL CODE)}

Since Cindy and Joanne each reasonably believed that her own use of force was justified, Cindy's force and Joanne's force would both be justified under $\S 3.04$ of the MPC.50 That both of the actors' use of force is justified does not present conceptual difficulties since proponents of the subjective theory readily acknowledge that conflicting justifications may occasionally arise. ${ }^{51}$

\section{CONCLUSION}

Hypothetical 2 does not present difficulties for $\S 3.04$ of the MPG, ${ }^{52}$ but is substantially problematic for both Robinson's and Fletcher's objective theories of justification. Under those theories, if both actors' use of force is justified or neither actor's use of force is justified, paradoxically each actor's use of force is both justified and not justified. Since there is no relevant basis, in principle, for differentiating Cindy's conduct from Joanne's conduct as to which is justified, and the nature of justification is universal, it cannot be the case that one actor's force is justified and the other actor's force is unjustified. Yet, for one of the actor's force to be justified, the other actor's force must be unjustified; for one of the actor's force to be unjustified, the other actor's force must be justified. This conclusion is contradicted by the universal character of justification and the fact that there is no basis for differentiating between the actors' conduct as to which is justified. The objective theories' treatment of this hypothetical situation is self-contradictory. As a result; whether Cindy's force or Joanne's force is justified is paradoxically indeterminate under the objective theories.

Further, a requirement of knowledge of the justificatory circumstances, which perhaps circumvented the contradiction in Hypothetical 1, would not avoid the contradiction in Hypothetical 2. Since both Cindy and Joanne correctly apprehended what the other believed and that the other would imminently use force, each satisfies the knowledge requirement. One might argue, however, that each actor must know that the other actor will unjustifiably attack to satisfy the proposed knowledge requirement. Yet, such an issue would seem to be a legal conclusion rather than part of the knowledge of the factual circumstances giving rise to eligibility for a justification. If so, then Cindy and Joanne each have knowledge of the justificatory circumstances and the tentatively proposed amendment to the objective the-

50 Model Penal Code $\$ 3.04$.

51 See supra note 18.

52 Model Penal Code $§ 3.04$. 
ories fails to remove the paradox.

Suppose that to satisfy the proposed knowledge requirement, each actor must know that the other actor will unjustifiably attack. First, consider whether Cindy had knowledge that Joanne would unjustifiably attack her-i.e., whether Cindy's reasonable belief was correct. As discussed above, it is indeterminate whether Cindy's reasonable belief is correct. As a result, it is indeterminate whether Cindy had such knowledge. A similar form of argument would also demonstrate that it is indeterminate whether Joanne's reasonable belief was correct and therefore, it is indeterminate whether Joanne had such knowledge.

Some critics might argue that since it is indeterminate whether each had the requisite knowledge, neither actor satisfies the tentatively proposed amendment requiring knowledge of the justificatory circumstances. Those critics would consequently conclude that neither actor's force is justified, and the logical contradiction derived from the objective theories in their present form would not arise under their tentatively amended formulation. But that argument is flawed.

If it is claimed that neither actor had the requisite knowledge of the justificatory circumstances, then neither actor's force would be justified under the tentatively amended objective theories. If neither actor's force is justified, then each actor was unjustifiably attacked. If each actor was unjustifiably attacked, then each actor was correct (Cindy and Joanne each reasonably believed that the other would imminently and unjustifiably attack). If each actor's reasonable belief was correct, each had knowledge of the justificatory circumstances. The claim that neither actor had the requisite knowledge of the justificatory circumstances leads to the self-contradictory conclusion that each actor does have the requisite knowledge. As a result, the tentatively proposed amendment requiring knowledge of the justificatory circumstances would not avoid the logical contradiction. Similarly, amending the objective theories so as to require both justificatory purpose and knowledge of the justificatory circumstances would also fail to dislodge the paradox. Section VI will discuss a possible amendment to the objective theories which perhaps avoids this self-contradiction.

\section{COUNTER-ARGUMENTS}

\section{A. ATYPICAL HYPOTHETICALS}

Although the situations depicted in Hypotheticals 1 and 2 are unlikely to transpire with great frequency, they are nonetheless plausible and possible. Therefore, the fact that they demonstrate that the ob- 
jective theories are contradictory is significant, and should be of substantial concern to proponents of, and jurisdictions employing, an objective theory of justification..$^{53}$ Furthermore, Hypothetical 1 is only a slight variation on Fletcher's hypothetical. Thus, proponents of the objective theory cannot criticize it as being too atypical without weakening the strength of their own hypotheticals and the contentions which they buttress. In fact, the use of hypotheticals to examine the soundness of a theory or to illuminate an aspect of criminal law is supported by Fletcher himself: "I have addressed the possible implications of treating the theoretical solution of hypothetical problems as a matter of high priority." ${ }^{4}$ Today's unlikely hypothetical may well be tomorrow's paradigmatic example. ${ }^{55}$

\section{B. SIMULTANEITY}

Proponents of an objective theory might also argue that the simultaneous use of force by the actors in Hypotheticals 1 and 2 is impossible because given sufficient precision, it would always be possible to ascertain a temporal difference between the force employed by each actor, however slight. However, while simultaneity may be unlikely, it is not impossible. Even Fletcher agrees "that two or more persons can simultaneously make an effort to shoot a wild fox."56

Nonetheless, an advocate of the objective approach to justification might still argue that there is something untoward about relying on simultaneity in a hypothetical situation. Yet proponents of an objective theory have employed the concept of simultaneity apparently without objection. Professor Sharon Byrd imposed simultaneity on

53 See supra text accompanying note 9 , note 10, text accompanying note 27 , note 39 and infra note 80, text accompanying note 122, note 132 .

54 George P. Fletcher, The Right Deed for the Wrong Reason: A Reply to Mr. Robinson, 23 U.C.L.A. L. Rev. 293, 294 n.6 (citing Fletcher, supra note 11). See also JoHN C. SMrth, JUSTIFICATION AND EXCUSE IN THE CRIMINAL LAW 28-29 (1989) ("Let me take a rather farfetched example - such examples are often the most vivid way of illustrating some legal principle or problem.").

55 Fletcher, supra note 20, at 228 (citing Fletcher, supra note 11) (emphasis added) (footnote omitted):

Some twenty years ago my imaginary character the "psychotic aggressor" made his debut in the pages of the Israel Law Review. Of all the hypothetical cases I have devised over the years, the story of the psychotic aggressor in the elevator, attacking someone who must defend herself, has become one of the most vigorous and longlasting. This unlikely case....

Another example of an influential hypothetical that transcended its own implausibility is Francis Bacon's "famous hypothetical case of two shipwrecked [drowning] sailors struggling to gain control of a plank [that will only keep one of the sailors afloat]." FLETCHER, supra note 1, at 819 (citing Francis Bacon, Elements of tHE CoMmon Lawes of ENGLAND (1630), in 13 Collected Works 131 (Montague ed., 1831)).

56 Fletcher, supra note 9, at 1358 (emphasis added). 
another commentator's hypothetical since "[o] therwise, the example loses its force." 57 Byrd also utilizes simultaneity in a hypothetical of her own: "If we both arrive at exactly the same time ...."58 One of the "cornerstones" of Fletcher's incompatibility thesis is his notion of incompatible acts, which he defines negatively: "Acts are incompatible if they cannot be performed simultaneously." 59 If simultaneous acts of force are impossible or dismissed as untoward, then Fletcher's definition loses all content.

If the use of simultaneity is somehow impermissible, the onus would seem to be placed on advocates of an objective theory to explain why. The subjective theory incurs no conceptual difficulties when applied to hypothetical situations involving simultaneous force. Why is only the objective theory rendered self-contradictory? Moreover, if there is nothing troubling about two persons reaching a plank simultaneously, arriving at a destination at exactly the same time, and shooting at a fox simultaneously, there is certainly nothing impermissible about two persons using force against each other simultaneously.

In any event, the following hypothetical does not depend on simultaneous force, but still creates conceptual difficulties for the objective theories. Suppose the situation is the same as Hypothetical 2, except that Cindy hits Joanne slightly before Joanne hits Cindy. Ultimately, the non-simultaneity of the force employed does not affect the objective theories' treatment of Cindy's and Joanne's conduct.

If both actors' use of force is justified or neither actor's use of force is justified, then paradoxically each actor's use of force is both justified and not justified at the same time. Perhaps, however, the non-simultaneity of the force employed provides a relevant basis for determining which actor's force is justified and which actor's force is unjustified. An outcome of one actor's force being justified and the other's force being unjustified might not be problematic for the objective theories.

First, consider whether Joanne's force is justified. If Joanne had not used force, Joanne would have sustained an even more forceful blow since Cindy's force would have been unimpeded. Therefore, it was necessary that Joanne used protective force. Since Joanne acted with justificatory intent and her force was proportional, as well as necessary, ${ }^{60}$ Joanne's force would be justified if Cindy's force was unjustified. Whether Joanne's force is justified would then depend on

57 Byrd, supra note 2, at 1333 n.132. In the text accompanying the footnote, Byrd states "[a]ssuming that both of these persons reach the plank at the same time." Id. at 1333.

58 Id.

59 Fletcher, supra note 9 , at 1358.

60 See supra notes 33 and 45 and accompanying text. 
whether Cindy's force was justified. A similar form of argument would also demonstrate that Cindy's force is justified if Joanne's force was unjustified. Whether Cindy's force is justified would then depend on whether Joanne's force was unjustified. A vicious circle ensues.

Next, consider whether or not Cindy's force is justified. Since Cindy hit Joanne first, arguably initiating the aggression, it is tempting to argue that Cindy's force is unjustified. Nonetheless, Cindy's force is eligible for justification since at the time she used force against Joanne, Cindy was subject to an imminent attack from Joanne.

Another argument is that since Cindy hit Joanne first, any justification for Cindy's force would "vest" prior to any justification for Joanne's slightly subsequent force. Under the objective theories, force used against justified force cannot be justified. If Cindy's force is justified, Joanne's force would be employed against Cindy's already justified force. Therefore, one might conclude that Cindy's force is justified, Joanne's force is unjustified, and the contradiction does not arise under conditions of non-simultaneous force.

However, the above analysis is problematic. First, Joanne's force being unjustified rests on the premise that Cindy's force is justified. Yet the same argument supporting Cindy's force being justified also supports Joanne's force being justified. Thus the underlying premise of the above argument (that Cindy's' force is justified) is untenable. Second, even if it were possible to justify only Cindy's force, a troubling anomaly arises. Justifying Cindy's force and not justifying Joanne's force, solely on the basis of Cindy's quickness and superior hand speed, would constitute a reductio ad absurdum. Had it been the case that Joanne was quicker and hit Cindy first, Joanne's force would be justified and Cindy's force unjustified. Thus, a slight difference in hand speed renders Cindy's act "right and proper"61 and the "superior social interest,"62 but transforms Joanne's identical, but slightly slower, conduct into legal and moral wrongdoing. It is absurd to think that a theory of criminal responsibility would attach such weight to as trivial a factor as hand speed. But if the anomaly of justifying the actions of the person who acts more quickly is to be avoided, objectivists would have to accept the logical contradiction of each actor being both justified and not justified at the same time. In turn, in attempting to avoid the logical contradiction resulting from both actors' use of force being justified or neither actor's use of force being justified, the reductio ad absurdum of justifying the quicker actor ensues. 
In contrast, $\S 3.04$ of the $\mathrm{MPC}^{63}$ would justify both actors' use of force without incurring any conceptual problems. Since each actor reasonably believed that her force was justified, the non-simultaneity of the force employed would not affect the subjective theory's analysis.

\section{FACTUAL UNCERTAINTY}

Supporters of the objective theories of justification might argue that the indeterminacy as to whether the actors' use of force in the hypotheticals is justified is factual and not theoretical or conceptual. As a result, they would assert that the hypotheticals do not demonstrate the contradictory nature of the objective theories. For instance, Fletcher states that in cases of factual uncertainty, it may be difficult to determine which actor's force is justified, but maintains that in a situation of conflict there is only one party that has the superior right to exercise force:

[I]n cases of incompatible conduct, one and only one party must have a right to prevail. It is undoubtedly difficult in many cases to determine who has this superior right. If our principle is that self-defense applies only against wrongful or unjust aggressors, then we might well encounter factual problems in determining who the aggressor is. The simple factual issue of who started the fight might not lend itself to factual reconstruction. There might be difficulties in principle in deciding whether someone who has provoked the fight is the aggressor or victim of the other's aggression. But to concede these difficulties is not to abandon the quest for the superior right in situations of conflict.

In modern legal thought, we are likely to confuse two distinct issues: (1) Can we reliably determine who has the superior right in a situation of forcible conflict? and (2) Is there a superior right that permits one and only one party to exercise force? I concede that we cannot always resolve the issues of fact and value in determining who has the right to resist aggression. But this difficulty provides little warrant for cynicism or nihilism about whether one party is acting rightfully and the other wrongfully. 64

However, the indeterminacy of the status of the actors' force in the hypotheticals, and the resulting logical contradictions from which the objective theories suffer, are not the result of factual uncertainty. The hypotheticals provide all the relevant facts necessary to ascertain whether each actor's force is justified. For example, it is not the case that one party used unjustified aggression first and the hypotheticals failed to provide the necessary information to determine which actor unjustifiably initiated the aggression. Hypotheticals 1 and 2 clearly state that the actors used force simultaneously. It is also not the case 
that provocation occurred, but there is insufficient information in the hypotheticals to ascertain which actor was the provoker.

The claim that insufficient factual information caused the logical contradictions raises two questions: First, precisely what information is not provided that would be necessary to dissolve the indeterminacy? Second, Hypothetical 1 furnishes no less factual information than Fletcher's original hypothetical regarding Dan and Allan ${ }^{65}$ (and perhaps furnishes more factual information) and since the information provided in the original hypothetical was presumably sufficient, how would the factual information in the altered hypothetical be insufficient? Advocates of the objective theories have no satisfactory reply to these questions.

Contrary to what Fletcher claims, these hypotheticals demonstrate instances in which, as a matter of principle, each actor in a conflict does and does not have a superior right to exercise force. Hypotheticals 1 and 2 provide substantial "warrant for cynicism or nihilism about whether one party is acting rightfully and the other wrongfully."66

\section{Procedural Ramifications}

Due to the logical contradiction of each actor in Hypotheticals 1 and 2 being simultaneously justified and not justified under the objective theories, the theoretical solution as to whether each actor is justified is paradoxically indeterminate. Suppose, however, that each actor in any one of the hypotheticals was charged with assault and battery, and brought to trial in a jurisdiction incorporating an objective theory of justification. Because of the allocations of the burdens of production and persuasion, the prosecution would be unable to show that either actor is unjustified, and the trier of fact would have to conclude that each actor's force is justified-a violation of both Fletcher's incompatibility thesis and Robinson's correlate principle.

Justification defenses are considered to be affirmative defenses. ${ }^{67}$ As an affirmative defense, the defendant actors would have the burden of production. ${ }^{68}$ To satisfy the burden of production, each actor must supply "sufficient evidence, considered in the light most favorable to the defendant and all reasonable inferences therefrom, to allow a rational factfinder to find the issue for the defendant by a

65 Fletcher, supra note 3, at 972-73.

66 Fletcher, supra note 9, at 1361.

672 RoBINSON, supra note 6, § 3-1(7), Model Codifications, app. A, at 565 ("All justification defenses defined in this Chapter are affirmative defenses.").

68 Id. \$ 1-5(2) (a), at 552 ("Unless otherwise provided, the defendant shall have the burden of production as to: (i) justification defenses described in Chapter 3 of this title."). 
preponderance of the evidence."69 For example, in Hypothetical 2, Cindy and Joanne would each be able to furnish evidence that she was attacked, that her force was necessary and proportional, and that she acted with justificatory purpose. Since the evidence would be considered in the most favorable light, ${ }^{70}$ it would appear that Cindy and Joanne would each be able to furnish the evidence necessary to satisfy the justification defense criteria.

The issue would then be submitted to the trier of fact and the prosecution would bear the burden of persuasion. ${ }^{71}$ "[T] he prosecution must prove (or negate, as the case may be) the existence of that issue beyond a reasonable doubt or the trier of fact must decide the issue against the prosecution."72 Since whether each actor's force is justified is paradoxically indeterminate, the prosecution would not be able to prove "beyond a reasonable doubt" that either actor's force is unjustified..$^{73}$ As a result, the trier of fact would be forced to conclude that both Cindy's force and Joanne's force were justified. ${ }^{74}$

Although the theoretical solution is indeterminate, the procedural rules advanced by an objective theorist appear to dictate that the trier of fact would determine that each actor was justified in her use of force. Therefore, the substantive principles of the objective theories, which state that conflicting or incompatible justifications are "logically impossible," 75 are in contradiction with the procedural rules governing justification defenses advocated by a proponent of the objective approach. Furthermore, the contradiction is not the result of inadequate or incomplete evidence regarding the justificatory circumstances. ${ }^{76}$

\section{Theoretical Ramifications}

Applying the objective theories to Hypotheticals 1 and 2 demonstrates that the objective theories are self-contradictory. If the subjec-

69 Id. $\S 1-5(2)(\mathrm{b})$, at 552.

70 If the evidence suggests that each actor's force is simultaneously justified and not justified, one might infer that each actor's force is justified or that neither actor's force is justified. A reasonable inference, made in the light most favorable to the defendants, is that each actor's force is justified.

712 Robinson, supra note 6, § 1-6(2), Model Codifications, app. A, at 552 ("Except as provided in Subsection (3) of this Section, the prosecution shall have the burden of persuasion on all issues."). Subsection (3) of § 1-6 does not provide an exception to § 1-6(2) regarding justification defenses. Id. § 1-6(3), at 552 .

72 Id. § 1-6(1) (a), at 552.

73 Id.

74 If the prosecution does not meet the burden of persuasion, "the trier of fact must decide the issue against the prosecution." Id.

75 Fletcher, supra note 3 , at 978 .

76 See supra notes 64 to 66 and accompanying text. 
tive theory was also subject to the effect of the paradoxes, the occurrence of the paradoxes under the objective theories would be comparatively less disturbing. Thus, the fact that the contradictions introduced in this Article arise only under objective theories should concern proponents of, and jurisdictions employing, an objective approach. ${ }^{77}$

As noted, Fletcher states that "we can use the concepts of justification and excuse only when we are willing to accept the logical consequences of applying them to particular cases of conflict."78 Even if advocates of an objective approach accept the logical contradictions derived from their theory, they still might argue that those contradictions are no more problematic than the conflicting justifications generated by the subjective theory's "assimilating a putative justification to an actual justification." 79 However, the conflicting or incompatible justifications derived from the subjective theory are not nearly as problematic as the logical contradictions (introduced in this Article) faced by the objective theories. The subjective theory's problem of conflicting justifications is a criticism only from the perspective of an objective theory; but the self-contradictions in the objective theories provide a criticism of the objective theories on their own terms. Although the subjective theory is flawed from a view external to itself, it is not self-contradictory. The objective theories, however, are internally inconsistent and illogical. ${ }^{80}$

The logical contradictions inherent in the objective theories have significant implications for the objective theories' view of the nature of justification. Fletcher states that justified conduct is "right and proper"81 and represents the "superior social interest." 82 Yet, if an actor's force can be simultaneously justified and not justified, as the objective theories' analysis of Hypotheticals 1 and 2 would suggest, then

77 See supra text accompanying note 9 , note 10 , text accompanying note 27 , note 39 and infra note 80, text accompanying note 122, note 132 .

78 Fletcher, supra note 9, at 1358.

79 FLETCHER, supra note 1, at 763.

$80 \mathrm{~A}$ comment by Fletcher indicates that logical inconsistency in a theory is unacceptable:

This Article commits itself to logical consistency as the indispensable foundation for effective dialogue and coherent criticism. Only if we accept consistency as the overriding legal value will we be troubled by the paradoxes and antinomies that lie latent in our undeveloped systems of legal thought. Grappling with uncovered paradoxes and antinomies will impel us toward consistent theoretical structures.

Fletcher, supra note 10, at 1264-65.

For Fletcher's further thoughts on the unacceptability of logical inconsistency in legal thought see supra text accompanying note 9 , note 10 , text accompanying note 27 and infra text accompanying note 122 and note 132 .

81 Fletcher, supra note 9 , at 1357-58.

82 FLETCHER, supra note 1, at 761. 
the actor's conduct is both "right and proper," 83 and wrong and improper at the same time. The actor's conduct represents the "superior social interest" 84 and the inferior social interest at the same time. Robinson contends that " $[\mathrm{t}]$ he nature of the justification principle is such that a given course of conduct either does or does not cause a net harm." 85 Justified conduct does not cause a net harm, but unjustifiable criminal conduct does cause a net harm. Yet, by applying the objective theories to Hypotheticals 1 and 2, each actor's force does cause a net harm and does not cause a net harm.

That an actor's force can be right and wrong can constitute the superior and inferior societal interest, and can yield a net benefit and a net harm, may provide support for Professor Joshua Dressler's contention that justified conduct may, in some situations, be that which is merely "tolerable" or "permissible." 86 Dressler suggests that there are strong justifications (conduct that is right and beneficial) and weak justifications (conduct that is merely permissible or tolerable). ${ }^{87}$ Killing a child aggressor, for example, would be conduct that is not desirable or beneficial but only tolerable and thus would be a weak justification. ${ }^{88}$ Fletcher counters that "[a] justified act would then appear to be something more than an excused act, but something less than one that the actor has a right to do. The concept of 'permissibility' captures this middle position. ... This is a powerful suggestion, but one that ultimately fails." 89 Yet, if an actor's force may be right and wrong at the same time, Dressler's middle position of permissibility more readily accommodates the situations depicted in Hypotheti-

83 Fletcher, supra note 9 , at 1357-58.

84 FLETCHER, supra note 1 , at 761.

852 RoBinson, supra note $6, \S 121$ (d), at 10 (footnote omitted).

86 Dressler, supra note 8, at 63-64, 69-77; Dressler, supra note 2, at $1161 \mathrm{n} .22$. For other arguments against Fletcher's view that justification necessarily entails right and proper conduct see Lawrence Alexander, Justifications and Innocent Aggressors, 33 WAYNE L. REv. 1177 (1987); Eric Colvin, Exculpatory Defences in Criminal Law, 10 Oxford J. Legal Stud. 381, 395-401 (1990); Greenawalt, supra note 2, at 1904-07; Husak, supra note 2, at 500; Morawetz, supra note 23, at 289 n.42.

87 Dressler, supra note 2, at 1161 n.22.

88 Id.

89 Fletcher, supra note 9, at 1359. For Fletcher's additional views on permissibility see Fletcher, supra note 3, at 977 ("The concept of the permissible enters to fill the apparent gap between the rightful and the wrongful.... The 'permissible' flows from a skepticism about the possibility of a single solution."). Fletcher contends that the concept of permissibility fails because incompatible justifications would then be possible, violence would be encouraged instead of suppressed, and intervenors could render aid to either party in a dispute. Fletcher, supra note 9, at 1359-60. Yet if the incompatibility thesis must be excised to avoid self-contradiction (as this Article will suggest), the above consequences will nonetheless arise. See infra text accompanying notes 91-96, 114-18. To avoid self-contradiction, the objective theories may have to accept that justified conduct includes that which is merely permissible. 
cals 1 and 2.90

Fletcher states that an "important" consequence of the justification-excuse distinction regards the rights of third parties. ${ }^{91} \mathrm{~A}$ thirdparty intervenor may justifiably come to the aid of an actor whose force is justified but may not justifiably interfere with such an actor. ${ }^{92}$ If the actor is excused (or the actor's conduct satisfies the definition of a criminal offense, but is not justified), a third-party intervenor may not justifiably use force in aid of the actor and may justifiably interfere with the actor's force. ${ }^{93}$ However, under the objective theories, if an actor's force is both justified and not justified at the same time, as is each actor's force in Hypotheticals 1 and 2, the intervenor can justifiably use force in aid of the actor and cannot justifiably use force in aid of the actor. Furthermore, since the intervenor would be using force against another actor whose force is simultaneously justified and not justified, the intervenor would be both justifiably interfering and unjustifiably interfering with the other actor's unjustified and justified force.

Considering the chaos described above, no one could claim that the objective theories are properly ordering "the matrix of legal relationships affected by a claim of justification." 94 Moreover, Fletcher states that "if our legal ideal is the suppression of violence, then we must employ a set of ideas that enables us to determine upon whose side we should intervene." 95 As seen above, the objective theories fail to determine which actor is eligible to receive aid from an intervenor, allowing an intervenor to pick either side. In the event of multiple intervenors, the objective theories would increase the violence rather than suppress it. By Fletcher's own stated criteria, the objective theories incorporate a set of ideas that must not be employed.

In light of Hypotheticals 1 and 2, are Fletcher's incompatibility thesis and Robinson's correlate principle valid? In order for Fletcher's thesis and Robinson's principle to be clearly wrong, both actors' use of force in one of the hypotheticals would have to be justified and only justified. However, each actor's force in the hypotheticals is not quite justified-it is justified and not justified at the same time. But, even though Fletcher's thesis and Robinson's principle appear to be technically correct, they may be meaningless and invalid. If

90 Under Dressler's framework, the actors in Hypotheticals 1 and 2 might be construed as having weak justifications under an objective approach.

91 FLETCHER, supra note 1, at 760-61, 830.

92 Id. at 760-61, 830, 859; 2 RoBINSON, supra note 6, \$ 3-1(3), Model Codifications, app. $\mathrm{A}$, at 565 .

93 FleTCHER, supra note 1 , at 760-61, 869-70; 1 Rosinson, supra note $6, \S 36$ (a) (3), at 165.

94 Fletcher, supra note 1 , at 763.

95 Fletcher, supra note 9, at 1360. 
the source of the logical contradictions derived from the objective theories is Fletcher's thesis and Robinson's principle, as the analysis of Hypotheticals 1 and 2 suggests and the next Section will argue, then they are logically meaningless. If a proposition $(P)$ results in $X$ and not $X$ at the same time, thereby violating the law of noncontradiction, ${ }^{96}$ the proposition is logically meaningless or invalid.

If Fletcher's incompatibility thesis is meaningless or invalid, Fletcher's theory loses the primary support for its tenet that putative justification should not be assimilated to actual justification. Fletcher contends that either of two propositions, "if accepted would lead to the distinction between actual and putative [justification]. The first proposition is that subjective belief cannot by itself render conduct justified . . . .97 The second proposition is the incompatibility thesis. ${ }^{98}$ The first proposition begs the question since the subjective theory maintains that reasonable subjective belief renders conduct eligible for justification. If the second proposition is logically meaningless or invalid, there is no reason to maintain a clear distinction between putative justification and so-called actual justification.

The fact that the objective theory is self-contradictory also has implications for the fields of comparative criminal law and comparative modes of legal analysis. The prevailing common law or Anglo-American approach to justification embodies the subjective theory of justification. ${ }^{99}$ The civil law or Continental approach incorporates an objective theory of justification which is said to be followed in Western Europe, Eastern Europe, the former Soviet Union, Latin America, and Japan. ${ }^{100}$ Fletcher states that the Continental approach utilizes "structured"101 legal thinking and emphasizes "the Right."102 "The Right stands for a monistic legal order, for the existence of one right answer in every legal dispute. The Right requires us to believe that only one party can be justified in any situation of conflict." 103 In contrast, the Anglo-American approach employs "flat"104 legal discourse, empha-

96 See supra note 39.

97 Fletcher, supra note 3, at 973.

98 Id. at 975.

99 Id. at $971-80$.

$100 \mathrm{Id}$. at 972.

$101 \mathrm{Id}$. at 951 ("Structured legal discourse proceeds in two stages: first, an absolute norm is asserted; and second, qualifications enter to restrict the scope of the supposedly dispositive norm.").

$102 \mathrm{Id}$. at $950-54$.

103 Id. at 980.

104 Id. at 951 ("Flat legal discourse proceeds in a single stage, marked by the application of a legal norm that invokes all of the criteria relevant to the resolution of a dispute."). One commentator has stated that " $[t]$ he distinction between flat and structured thinking may be a chimera." Morawetz, supra note 23, at 306 (footnote omitted). 
sizes "reasonableness," 105 and reflects a pluralistic legal order in which there may be "several reasonable solutions to a particular dispute ...."106 Fletcher contends that structured legal analysis and the Continental approach are superior because they do not yield incompatible justifications. ${ }^{107}$ As a result, a sharp distinction between putative justification and so-called actual justification can be maintained. ${ }^{108}$

Yet, the logical contradictions generated by the objective theories of justification cast doubt upon the claimed superiority of the civil law or Continental approach and structured legal discourse. Applying the objective theories to Hypotheticals 1 and 2 demonstrates that the Continental approach and structured legal thought produce not "one right answer," 109 but two contradictory answers. It would appear that the Continental approach and structured legal discourse reflect not a monistic legal order but a self-contradictory, pluralistic legal order.

Fletcher finds support for his conception of justification in Professor Ronald Dworkin's thesis that there is only one right answer in every dispute ${ }^{110}$ and "that one of the parties in every hard case has a right to a decision in his favor ...."111 However, Dworkin's thesis is reflected neither in the subjective theory, which generates conflicting justifications, nor in the objective theories, which both justify and do not justify each party's conduct in Hypotheticals 1 and 2. This paradox makes it impossible to determine which party has a right to a favorable decision. Thus, at least regarding conduct eligible for a justification, Dworkin's thesis appears to be invalid. ${ }^{112}$

\section{Amending the Objective Theories to Avoid SELF-CONTRADICTION}

Various amendments to the objective theories have been proposed which, if adopted, would successfully avoid the logical contradiction illustrated in Hypothetical 1. For instance, eliminating Fletcher's incompatibility thesis and Robinson's correlate principle

105 Fletcher, supra note 3, at 950-54.

106 Id. at 981.

107 Id. at 973.

$108 I d$.

109 Id. at 980.

110 Id. at 981 (citing Ronald M. Dworkin, No Right Answer?, in LAW, MORAIrTY AND SocrETY 58, 84 (Peter M.S. Hacker \& Joseph Raz eds., 1977)).

111 Id. at 981 n.139.

112 Dworkin's thesis emerges as a reply to H.L.A. Hart's claim that judicial discretion is inevitable since in some cases there is no single right answer but a plurality of reasonable solutions. See H.L.A. HART, The CONCEPT OF LAW 128-30 (1961). Dworkin argues that judicial discretion is unwarranted since there is always a single right answer in every legal dispute. See Ronald M. Dworkin, Taking Rights Seriously 36 (1977). 
would successfully circumvent the paradox. However, the self-contradiction can be dislodged by less drastic means. Instead of Fletcher's theory requiring justificatory purpose or knowledge of the justificatory circumstances, ${ }^{113}$ a requirement of justificatory purpose and knowledge of the justificatory situation, or simply knowledge of the justificatory circumstances might dissolve the paradox for both objective theories of justification. Nonetheless, that amendment would not dislodge the objective theories' self-contradiction in Hypothetical 2.

The self-contradiction facing the objective theories in their treatment of Hypothetical 2 may require an amendment excising Fletcher's incompatibility thesis and Robinson's principle (Amendment 1). Under this amended theory, force used against justified force could be justified, and the logical contradiction would dissolve. Both Cindy's and Joanne's force would then be justified (as would both actors' use of force in Hypothetical 1). The excisement of Fletcher's thesis and Robinson's principle avoids the conclusion that if both actors' use of force is justified then neither actor's force is justified. As a result, the paradox of Cindy's force and Joanne's force each being simultaneously justified and not justified would not arise.

Although Fletcher's incompatibility thesis and Robinson's correlate principle are at the core of the objective theories of justification, the proposed amended objective theories would still differ substantially from the subjective theory. Actors' reasonable, but incorrect, beliefs that they are being threatened with harm or that they are being attacked would still not suffice to render them eligible for a justification under the tentatively amended objective theories. An actual threat or actual force (from an objective view of the circumstances) would still be a necessary condition for an actor's force to be justified. Thus, the objective theories would continue, in their tentatively amended forms, to exclude putative justification from so-called actual justification.

The proposed amended objective theories would nonetheless incur substantial difficulties. Robinson, in commenting on one state's self-defense provision, provides an apt criticism of the proposed amended objective conceptions of the self-defense justification:

Some [statutes] fail to restrict properly the authorized use of defensive force, providing instead a justification whenever it is necessary to defend against "the use ... of physical force." Such a formulation is clearly too broad, for it contravenes the logic of justifications by apparently permitting defensive force in response to a justified attack. Suppose $X$ unjustifiably attacks $Y$, and $Y$ lawfully defends through the use of physical force. Such a provision would apparently allow $X$ to then use additional force

113 FletChER, supra note 1 , at 559-60, 565. 
in response to $Y$ 's justified defensive force. ${ }^{114}$

The amended objective theories would fall prey to the same criticism since they would also justify $X$ 's additional force. Thus, in avoiding the logical contradictions derived from the unamended objective theories, each amended objective theory "contravenes the logic of justifications."115

Fletcher's original hypothetical involving Dan's reasonable, but mistaken, attack against Allan more fully illuminates this problem. ${ }^{116}$ Under the present and amended objective theories, Dan's attack would not be justified since Dan was not actually threatened or subjected to force, and Allan's use of force against Dan would be justified. Yet any force Dan used subsequent to Allan's force would be eligible for justification (clearly an unfortunate result under the amended formulation of the objective theory), since Dan was subjected to actual force. At this point, Dan and Allan would have conflicting justifications. Furthermore, an intervenor could justifiably come to the defense of either Dan or Allan or even switch back and forth. In the event of multiple intervenors, one or some intervenors could justifiably aid Dan, and other intervenors could justifiably aid Allan. The amended objective theories, though free of self-contradiction, would fail to properly order "the matrix of legal relationships"117 and would create situations of legal anarchy for which the subjective theory has been criticized. ${ }^{118}$

The adoption of an additional rule might remedy this problem. The rule might take the following form: an actor whose force is initially unjustified is barred from justifiably using force against an actor whose force is justified (Amendment 2). Amendment 2 would prevent Dan's second use of force, in Fletcher's hypothetical, from being justified; prevent Dan and Allan from having conflicting justifications; and permit intervenors to justifiably aid only Allan. The rule would avoid legal anarchy and restore the proper "matrix of legal relationships." 119 Furthermore, Amendment 2 would still allow aggressors whose force is initially unjustified to use force justifiably against their victims, if the victims used excessive (and thus unjustified) force against them. Amendment 2, however, would have no effect on $\mathrm{Hy}-$ potheticals 1 and 2 and, thus, would not completely bar conflicting

114 Paul H. Robinson, Criminal Law Defenses: A Systematic Analysis, 82 Colum. L. Rev. 199, 276 (1982) (footnote omitted) (quoting ConN. GEN. Stat. ANN. § 53a-19(a) (West 1972)).

115 Id.

116 Fletcher, supra note 3, at 972-73.

117 FLETCHER, supra note 1 , at 763.

118 Fletcher, supra note 9, at 1359.

119 FLETCHER, supra note 1, at 763. 
justifications. ${ }^{120}$

Amendment 1, excising Fletcher's thesis and Robinson's principle, resolves the logical contradictions in the objective theories as applied to Hypotheticals 1 and 2, but creates new difficulties not encountered by the unamended objective theories. The adoption of Amendment 2 corrects some of those difficulties, but also causes new problems not faced by the unamended objective theories.

Consider the following two examples: First, suppose a police officer uses justifiable force in the arrest of a criminal suspect. The suspect then uses only that force necessary to resist the police officer's force. Under the unamended objective theories, the suspect's force would be unjustified (presumably the correct result) since it was used against the police officer's justified force. The suspect's force would be justified, however, under Amendment 1 of the amended objective theories since the suspect used force against actual force. Also, Amendment 2 would not bar a justification for the force because the suspect did not previously or initially use unjustified force.

Second, suppose $A$ justifiably uses force against $B$ under a choice of evils justification. ${ }^{121} B$ then uses only that force necessary to resist $A$ 's force. $B$ 's force, employed against $A$ 's justified force, would not be justified (presumably the correct result) under the unamended objective theories. But since $B$ used force against actual force and did not previously or initially use unjustified force, $B$ 's force (as well as $A$ 's force) would be justified under the amended objective theories.

Since justifying the suspect's force and $B$ 's force is undesirable, the tentatively amended objective theories are untenable. Could the tentatively proposed amended objective theories be further revised so as to justify neither the suspect's force nor B's force? Excising Amendment 1 (i.e., reinstating Fletcher's thesis and Robinson's principle) would bar an actor's force from being justified when used against justified force. Thus, the suspect's force and $B$ 's force would be unjustified. But eliminating Amendment 1 would reintroduce the logical contradictions arising in Hypotheticals 1 and 2.

120 In Hypothetical 1, neither Dan nor Allan initially used unjustified force. Similarly, neither Cindy nor Joanne initially used unjustified force in Hypothetical 2. In the variation of Hypothetical 2, in which Cindy hit Joanne slightly before Joanne hit Cindy, Cindy could not be construed to have initially used unjustified force. Since Cindy's use of force was necessary, Cindy did not initially use unjustified force despite being the initial party to use force.

121 A choice of evils or lesser evils justification applies when an actor's conduct constitutes a criminal offense, but, in light of the circumstances, does not constitute a net harm or evil. 2 RoBINSON, supra note $6, \S 124$ (a), at 46 . For an objective theory's formulation of the justification, see, for example, id. Model Codifications, app. A, § 3-2, at 565. For a subjective theory's formulation, see, for example, Model Penal Code $\$ 3.02$. 
Another amendment, providing that self-defense force cannot justifiably be employed against justified police force or justified choice of evils force (Amendment 3), would prevent both the suspect's force and $B$ 's force from being justified. Yet this approach may not be altogether satisfactory. It has a blatantly ad hoc quality. The objective theories would no longer provide a unified, comprehensive conception of justification. It might offend the logic of justifications to say that self-defense force could be justifiably employed against justified selfdefense force (Hypotheticals 1 and 2) but not against justified police force or justified choice of evils force. Such a makeshift framework would inevitably succumb to as yet unanticipated situations requiring still further revisions to avoid anomalies.

A few tentatively proposed amendments to the objective theories have been briefly sketched. Amendment 1 avoids the logical contradictions, but allows conflicting or incompatible justifications. It also creates additional conceptual difficulties. Amendments 2 and 3 resolve those difficulties-with marginal success-but create additional ones. Each revision provides a solution to one anomaly while giving rise to yet another anomaly. Of course, if these problems cannot be overcome, the objective theory could be abandoned in favor of the subjective theory, or perhaps there are other viable ways to circumvent the logical contradictions derived from the objective theories.

Fletcher suggests a methodology for resolving paradoxes in legal thought:

When a paradox is uncovered, we can restore consistency in our legal structures in one of two ways: (1) by finding or constructing a distinction ... that dissolves the paradox or (2) by abstaining from the legal practice that leads us into the contradiction. We can think of these as the theoretical and legislative alternatives. Consistency requires either that we change theory to conform to practice, or change practice to conform to theory. Neither of these polar alternatives seems satisfactory. If we manipulate theory in order to conform to practices that seem sound to us, theory becomes nothing more than a pliable tool of rationalization. Yet it seems difficult to abandon a practice like [requiring that an actor face unjustified force, or a threat of unjustified force, in order for the actor's force to be eligible for justification] . . . simply because we have not yet found the proper distinction for resolving the paradox at the level of theory. ${ }^{122}$

In exploring possible amendments to the objective formulation of justification, this Article has pursued what Fletcher terms the legislative alternative. Perhaps a distinction could be constructed that would dissolve the logical contradictions without generating additional anomalies. Articulating such a distinction, however, seems, at present, 
elusive.

\section{Conclusion}

The archetypal self-defense scenario consists of a culpable aggressor wrongfully attacking an innocent victim who rightfully, for selfprotection, uses what otherwise would be wrongful force against the aggressor. ${ }^{123}$ It might be said that in such self-defense situations two wrongs make a right. Yet in applying the objective theories of justification to Hypotheticals 1 and 2, two rights make two wrongs, ${ }^{124}$ which generate two rights ad infinitum. Each actor's rightful and justified conduct transforms the other actor's rightful and justified conduct into wrongful and unjustified conduct. In turn, each actor's wrongful and unjustified conduct causes the other actor's wrongful and unjustified conduct to be rightful and justified conduct. A determination that each actor's use of force is justified (or unjustified) "cannibalizes itself" 125 and generates the opposite conclusion. A vicious circle or "infinite alternation of opposite conclusions"126 ensues. Consequently, each actor's force is simultaneously justified and unjustified in violation of the law of noncontradiction. ${ }^{127}$

The contradiction incurred by both objective theories, in regard to Hypothetical 1 may be circumvented by an amendment requiring knowledge of the justificatory circumstances. It appears, however, that only an amendment to the objective theories, which eliminates Fletcher's incompatibility thesis and Robinson's correlate principle, provides a resolution to the contradictions in both Hypotheticals 1 and 2. Yet, amending the objective theories in this manner creates an amended objective theory which "contravenes the logic of justifications. . . " 128 The tenet that force cannot justifiably be used against justified force is at the center of the objective theories of justification. Its removal not only eviscerates the objective theories, but also creates a host of new problems not encountered by the unamended objective theories. The adoption of a second amendment may avoid some of

123 See Gerald Epps, Any Which Way but Loose: Interpretive Strategies and Attitudes Toward Violence in the Evolution of the Anglo-American "Retreat Rule, "55 LAW \& CONTEMP. ProBs. 303, 303-04 (1992).

124 One commentator has described the paradox of blackmail by asking "[w]hy do two rights make a wrong?" James Lindgren, Blackmail: An Afterword, 141 U. PA. L. REv. 1975, 1975 (1993).

125 Pierre Schlag, Cannibal Moves: An Essay on the Metamorphoses of the Legal Distinction, 40 STAN. L. Rev. 929, 958 (1988) (discussing modes of legal discourse which paradoxically circle back and consume themselves).

126 Id. at 947.

127 See supra note 39.

128 Robinson, supra note 114, at 276. 
the resulting difficulties. However, that amendment gives rise to additional anomalies which require yet another amendment. It is not clear whether this third amendment provides an entirely satisfactory solution. If the difficulties are considered insuperable, adopting the subjective theory of justification may be the only alternative.

Although the adoption of Amendment 1 would expunge the logical contradictions, and further amendments arguably resolve the resulting anomalies, neither the unamended nor the amended formulations can support the objective theories' depiction of the nature of justification. Applying the unamended objective theories to Hypotheticals 1 and 2 results in each actor's use of force being both justified and not justified at the same time. Even under the tentatively proposed amended objective theories, the actors' use of force generates conflicting and incompatible justifications. Under either the amended or unamended objective theories, it is no longer the case that only one party has the superior right to prevail. Furthermore, how can each opposed actor's conduct be right and proper and represent the superior social interest? Justified conduct cannot be considered necessarily right, good, and proper; it must be conduct that is permissible, tolerable, and reasonable. The objective theories of justification, unamended or amended as proposed, fail to embody the Right and "a monistic legal order, for the existence of one right answer in every legal dispute." 129

To avoid self-contradiction, the objective theories may be forced to reflect a pluralistic legal order with reasonableness as the paramount value. Thus, both parties to a dispute may be justified in that their conduct is permissible, reasonable, or tolerable. Yet if reasonableness is to be the underlying value of an amended objective theory of justification free of self-contradiction, there is no reason to require that an actor's force be actually necessary. Actors' reasonable beliefs suffice to render their conduct eligible for a justification. There is no reason not to assimilate putative justification to an "actual" justification. If reliance on the Right leads to a self-contradiction ${ }^{130}$ and an emphasis on reasonableness, while conceptually consistent, is nonetheless deemed "philosophically dubious,"131 perhaps proponents of,

129 Fletcher, supra note 3 , at 980.

130 See Kant, supra note 20.

131 Fletcher, supra note 7, at 662 . Fletcher's comment addresses the subjective theory of justification employed by the MPC: "[T] he infelicitous implication that someone who believes, mistakenly, that he is acting in self-defense actually is justified in what he is doing. I have done battle elsewhere with this philosophically dubious conception of justification .... . Id. (footnote omitted). 
and jurisdictions employing, an objective approach will be challenged to establish a new theoretical framework ${ }^{132}$ to support an objective conception of justification. must reach a deeper understanding of the legal premises that guide our thinking."). 